DOI: 10.46340/ephd.2021.7.4.5

Volodymyr Latenko

ORCID ID: https://orcid.org/0000-0003-1407-453X

The State Institution «Institute of World History of the National Academy

of Sciences of Ukraine», Kyiv, Ukraine

\title{
U.S. INFLUENCE ON THE DEPLOYMENT OF THE UN PEACEKEEPING MISSION IN THE CONGO (JULY-AUGUST 1960)
}

\section{Володимир Латенко}

Державна установа "Інститут всесвітньої історії НАН України», Київ, Україна

\section{ВПЛИВ США НА РОЗГОРТАННЯ МИРОТВОРЧОЇ МІСЇ̈ ООН В КОНГО (ЛИПЕНЬ-СЕРПЕНЬ 1960 Р.)}

The article considers the deployment and operation of the United Nations Peacekeeping Mission in the Congo (ONUC) during the first two months after its independence. Particular attention is paid to the study of the impact on the formation of the ONUC mission of the United States of America during the administration of D. Eisenhower in a bipolar confrontation with the USSR. In the process of decolonization of Sub-Saharan Africa, The United States was a key foreign policy force, which resisted attempts of communist penetration to the continent. Based on declassified materials of the State Department and the US Central Intelligence Agency analyzed the methods of official and informal influence of the American government on the creation and activity of the peacekeeping contingent in the Congo and the stabilization of the situation in the country are analyzed. In addition, the main features of the US interaction with the government of $P$. Lumumba, who was considered a Soviet satellite in the White House, were traced. It has been established that the United States avoided providing direct assistance to the Congolese government during this period and acted exclusively through UN instruments. This is due to the attempt of official Washington not to provoke the USSR for direct interference in the affairs of the Congo. Despite this, such an intervention could not be avoided.

Thus, US policy on the Congo during the administration of D. Eisenhower carried out through official diplomatic missions and an informal CIA unit in Leopoldville, as well in the international arena, in the GA and the UN Security Council, was aimed at stabilizing the situation in the new country through the deployment of the UN Peacekeeping Mission on its territory. Between July and August 1960, acting exclusively through UN instruments and mechanisms, refraining from providing direct assistance to the Congolese government, The United States sought to prevent similar direct involvement in Congolese affairs by the USSR. However, the Soviet government in late August 1960 went to help the government of P. Lumumba, which was limited in nature but was contrary to UN procedures. These actions provoked the risk of the spread of the Cold War in Sub-Saharan Africa and led to a change in US policy towards the Congo in the following years. Keywords: USA, Congo, UN Peacekeeping Mission in Congo (ONUC), USSR, Patrice Lumumba.

На початку 1960-х рр. в Субсахарській Африці розгорнулися процеси деколонізації та появи цілої низки незалежних країн. Нерідко нові держави виявлялися не готовими до повноцінного існування в умовах незалежності, що призводило до нестабільності вже з перших днів після ії отримання. Саме так сталося з Республікою Конго (Леопольдвіль), події в якій увійшли в історію під назвою «Конголезька криза». Стабілізація ситуації в країні потребувала введення миротворчого контингенту ООН та активної участі світових центрів впливу, зокрема США та СРСР, кожен з яких намагався залучити нову республіку до своєї орбіти впливу на континенті. 
В історіографії дослідження можна виокремити три групи праць. Першу складають роботи переважно американських істориків, що фокусували увагу на політиці США в регіоні Субсахарської Африки та Конго зокрема. До них належать праці таких авторів як К. Джеймс ${ }^{1}$, В. Маунтз ${ }^{2}$, М. Вільямс ${ }^{3}$. До другої групи слід віднести праці, присвячені комплексному висвітленню всього періоду Миротворчої місії ООН в Конго. Це, зокрема, робота Б. Коул ${ }^{4}$. Третя група представлена дослідженнями, які ставлять події Конголезької кризи 1960 р. в контекст біполярного протистояння часів «холодної війни». До неї належать праці американських науковців Л. Намікас ${ }^{5}$ і С. Сулеймана ${ }^{6}$, а також російського історика В. Мазова ${ }^{7}$. Крім вище вказаних напрацювань дослідників, було використано комплекс розсекречених матеріалів Державного департаменту США, опублікованих у багатотомному виданні «Закордонні відносини Сполучених Штатів» (т. 14) ${ }^{8}$, а також у виданні «Закордонні відносини Сполучених Штатів» (т. 23) доступу на офіційному сайті Державного департаменту США, а також тексти резолюцій ООН.

Республіка Конго отримала незалежність від Бельгії 30 червня 1960 р. Вже з перших днів конголезька держава зіткнулася з серйозними труднощами на шляху свого становлення. Так, вже 2 липня 1960 р. відбулися міжплемінні сутички в Леопольдвілі і Лулуабурзі, що стали прологом періоду нестабільності в історії суверенного Конго, відомого як «Конголезька криза».

5 липня 1960 p. угарнізонах Леопольдвіля і Тісвіля почалося повстання серед рядових конголезців у лавах колишніх колоніальних воєнізованих формувань («Force Publique»), керівництво яких повністю складалося із бельгійського офіцерського складу ${ }^{10}$. Рішення прем'єр-міністра П. Лумумби реформувати ці збройні загони у Конголезьку національну армію (КНА), на чолі якої мав стати етнічний конголезець Віктор Лундула, а начальником штабу КНА - полковник Сесе Секо Мобуту, а також надати підвищення по чину всім рядовим, не призвели до відновлення порядку в країні ${ }^{11}$.

За подіями, що розгорталися, уважно стежили як у Брюсселі, так і у Вашингтоні через діяльність своїх дипломатичних місій. Посол США у Леопольдвілі К. Тімберлейк 9 липня 1960 р. повідомляв Держдепартамент про зусилля уряду П. Лумумби, зазначаючи, що прийнятих кроків для стабілізації може виявитися недостатньо ${ }^{12}$.

Невдоволення проти офіцерів колишньої метрополії швидко переросло у хвилю антибельгійського руху та нападів на жителів країни європейського походження, що у свою чергу спричинило їх еміграцію з території Конго і нестачу професійних кадрів у багатьох сферах.

За день до дня набуття незалежності Конго, 29 червня 1960 р., було укладено бельгійськоконголезький договір про дружбу, який, серед іншого, передбачав збереження за Бельгією військових баз у містах Кітона i Каміна, а також можливість надання військової допомоги на заклик конголезького уряду. Однак, договір не був ратифікований обома сторонами. В умовах, що склалися, офіційний Брюссель надіслав запит до прем’єр-міністра П. Лумумби щодо застосування бельгійських військових із числа розміщених у Каміні і Кітоні задля відновлення правопорядку. Після отримання

\footnotetext{
${ }^{1}$ James, K. (1989). The United States and the Congo from June 30, 1960 to January 17, 1961. College Park.

${ }^{2}$ Mountz, W. (2014). Americanizing africanization: the Congo Crisis, 1960-1967. The University of Missouri-Columbia, Columbia.

${ }^{3}$ Williams, M. (1991). America and the first Congo Crisis, 1960-1963. Irvine: University of California.

${ }^{4}$ Cole, B. (1967). The United Nations Peace-Keeping Operations: The Actions and Policies of the African Nations in the Congo. Washington, D.C.: Georgetown University.

${ }^{5}$ Namikas, L. (2002). Battleground Africa: The Cold War and the Congo Crisis, 1960-1965. Los Angeles: University of Southern California.

${ }^{6}$ Souleyman, S. (2013). Cold War battleground in Africa: American foreign policy and the Congo Crisis, January 1959 - January 1961. Fayetteville: University of Arkansas.

${ }^{7}$ Мазов, С. (2015). Холодная война в «сердие» Африки. СССР и Конголезский кризис, 1960-1964.

Москва: Русский Фонд Содействия Образованию и Науке.

${ }^{8}$ FRUS (2013). Foreign Relations of the United States, XXIII, Congo, 1960-1968. Washington: United States Government Printing Office.

${ }^{9}$ FRUS (2013). Foreign Relations of the United States, XIV, Africa, 1958-1960. Washington: United States Government Printing Office.

${ }^{10}$ Cole, B. (1967). The United Nations Peace-Keeping Operations: The Actions and Policies of the African Nations in the Congo. Washington, D.C.: Georgetown University, 15.

${ }^{11}$ Mountz, W. (2014). Americanizing africanization: the Congo Crisis, 1960-1967. Columbia: The University of Missouri-Columbia, 14.

${ }^{12}$ FRUS (1960). Telegram From the Embassy in the Congo to the Department of State (July, 9), XIV, Africa, $1958-1960$. Doc. 109.
} 
відмови, керуючись захистом своїх громадян на конголезькій території, уряд колишньої метрополії вирішив діяти на власний розсуд. 9 липня 1960 р. посол США у Бельгії В. Бурден повідомляв про ситуацію, що склалася у зв'язку із запланованою бельгійською воєнною інтервенцією в Конго. Американський посол висловив занепокоєння Держдепартаменту США з приводу широкої негативної міжнародної реакції на заплановане Бельгією втручання у справи незалежної країни. Офіційний Брюссель запевнив, що дії Бельгії в Конго не будуть суперечити Статуту ООН. Крім того, бельгійська сторона посилалася на статтю 6 бельгійсько-конголезького договору, який передбачав можливість втрутитися для захисту своїх громадян та майна. Водночас, у Брюсселі проігнорували відсутність запиту і згоди з боку конголезького уряду на ці дії, а також факт не набуття договором чинності через процедуру його ратифікації ${ }^{1}$.

10 липня 1960 р. під приводом порятунку своїх громадян Бельгія відправила до Конго 1200 військових, зокрема десантників, які мали підсилити 2500-й контингент двох існуючих баз. Ці сили були розгорнуті не лише у Кітоні і Каміні, але й за їх межами, зокрема, у Катанзі, яка була переважно населеною європейцями та залишалася найбільш стабільною провінцією країні ${ }^{2}$.

Того ж дня посол В. Бурден повідомляв про зустріч із главою МЗС Бельгії П. де Віньї, під час якої зазначив останньому, що ніхто не може заперечувати проти використання військ у гуманітарних цілях. Однак, загальне підтримання порядку є функцією суверенної влади на місцях, і якщо Бельгія публічно оголосить, що бере на себе цю функцію, без запиту Конголезької Республіки, то ризикує отримати звинувачення у спробі відновлення свого колоніального статусу ${ }^{3}$. Американський дипломат вважав, що посольство США в Леопольдвілі через свого очільника К. Тімберлейка має закликати президента Ж. Касавубу спрямувати офіційний запит до ООН про допомогу для відновлення суспільного порядку та законності на території Конго. На початках бельгійські військовослужбовці могли виконувати свої функції в якості першого контингенту в рамках місії $\mathrm{OOH}^{4}$.

Крім уже існуючих викликів, перед конголезькою республікою постало питання збереження територіальної єдності країни 5 . Так, у Телеграмі від посольства США у Бельгії до Держдепартаменту від 11 липня 1960 р. повідомлялося, що прем’єр-міністр провінції Катанга, М. Чомбе, збирається оголосити про незалежність від Конго. Лідера сепаратистів цікавило питання, чи готові Сполучені Штати визнати незалежну Катангу. Через неофіційні канали зв'язку була надана відповідь, що США не визнають незалежність провінції. Незважаючи на це, М. Чомбе висловив готовність навіть в такому випадку продовжити свої дії, спрямовані на відокремлення 6 .

У цій ситуації адміністрація Д. Ейзенхауера вже не могла повністю покладатися Бельгію, свого союзника по НАТО, дії якого спричинили загострення протистояння у його колишній колонії. США прагнули уникнути безпосереднього втручання усправи Конго, діючи через механізми ООН. Зокрема, у Телеграмі від Держдепартаменту до Місії США при ООН зазначалося, що остання може зіграти важливу роль у відновленні громадянського спокою та порядку, а також підтриманні територіальної цілісності .

12 липня 1960 р. посол США у Леопольдвілі К. Тімберлейк, який був присутнім на засіданні конголезького уряду, отримав письмовий запит на введення американського контингенту на територію Конго задля підтримання правопорядку. Уряд П. Лумумби покладав надію на Вашингтон, пропонуючи спрямувати 3000 американських військових ${ }^{8}$. Влада Конго надала дозвіл військовим літакам США здійснювати посадку в будь-якій точці країни.

\footnotetext{
${ }^{1}$ FRUS (1960). Telegram From the Embassy in the Congo to the Department of State (July, 9), XIV, Africa, $1958-1960$. Doc. 110.

${ }^{2}$ Williams, M. (1991). America and the first Congo Crisis, 1960-1963. Irvine: University of California, 16-17.

${ }^{3}$ FRUS (1960). Telegram From the Embassy in Belgium to the Department of State (July 10), XIV, Africa, $1958-1960$. Doc. 113.

${ }^{4}$ FRUS (1960). Telegram From the Embassy in Belgium to the Department of State (July 10), XIV, Africa, $1958-1960$. Doc. 111 .

${ }^{5}$ Kabwit, G. (1975). The evolution of the Congo foreign policy from 1960-1970: A case study in the determinants influencing the making of foreign policy. Washington: The American University, 155.

${ }^{6}$ FRUS (1960). Telegram From the Embassy in Belgium to the Department of State (July 11), XIV, Africa, $1958-1960$. Doc. 114.

${ }^{7}$ FRUS (1960). Telegram From the Department of State to the Mission at the United Nations (July 11), XIV, Africa, 1958-1960. Doc. 115.

${ }^{8}$ Souleyman, S. (2013). Cold War battleground in Africa: American foreign policy and the Congo Crisis, January 1959 - January 1961. Fayetteville: University of Arkansas, 53.
} 
У Вашингтоні у відповідь на заклик конголезького уряду про військову допомогу, заявили, що планують провести консультації з ООН стосовно цього питання. Зокрема, під час телефонної розмови держсекретаря К. Гертера з президентом Д. Ейзенхауером, була узгоджена позиція проти відправлення американського контингенту до Конго. Д. Ейзенхауер висловив думку про помилковість одностороннього входження американських військових до Конго, а також заявив про підтримку контакту із $\mathrm{OOH}^{1}$.

12 липня 1960 р. на адресу штаб-квартири ООН надійшла офіційна телеграма за підписом президента Конго Ж. Касавубу і прем’єр-міністра П. Лумумби з проханням про термінову військову допомогу у зв'язку з відділенням провінції Катанга, наростанням внутрішнього хаосу та відкритою воєнною інтервенцією з боку бельгійських військ поза межами своїх баз і всупереч двосторонньому договору від 29 червня $1960 \mathrm{p}$.

У Білому домі вважали, що оскільки пропозиція про спрямування миротворчої місії на територію Конго офіційно надійшла від африканських держав, ніхто з постійних членів РБ ООН, особливо СРСР, не стане користуватися правом вето і рішення буде прийнято. Також висловлювалися побоювання, що конголезький уряд може запросити допомоги у китайських комуністів, однак якщо СРСР підтримає проект резолюції, інші комуністичні країни не ризикнуть втручатися самостійно ${ }^{2}$.

Позиція США полягала у тому, щоб не втручаючись безпосередньо, надавати всебічну підтримку для створення Сил ООН в Конго. Сполучені Штати висловлювали готовність надати допомогу у вигляді транспорту, зв'язку та іншої матеріально-технічної підтримки. У Вашингтоні прагнули якнайшвидшої присутності ООН в Конго, щоб унеможливити односторонню допомогу представників комуністичного блоку, поза межами ООН. Про це йдеться, зокрема, в інформаційному меморандумі керівника Африканського відділу Дж. Саттервейта до держсекретаря К. Гертера, де зазначалося, що США повинні не допустити проникнення до Конго комуністів. На думку Дж. Саттервейта, потрібно бути готовими до здійснення швидких, ефективних та, в разі необхідності, досить вартісних програм, щоб такого проникнення не відбулося ${ }^{3} .3$ цією метою пов'язана й активізація діяльності підрозділу ЦРУ в Леопольдвілі, очільником якого у липні 1960 р. став Лоуренс Девлін.

На 873-му засіданні РБ ООН від 13/14 липня 1960 р. було ухвалено резолюцію №143 про утворення миротворчої місії ООН в Конго, яка включала три пункти. У першому з них містився заклик до уряду Бельгії вивести всі свої війська з території Республіки Конго. Другий пункт уповноважував Генерального секретаря у консультаціях із конголезьким урядом вжити всіх необхідних заходів для надання військової допомоги доти, поки сили національної безпеки, завдяки технічній допомозі ООН не зможуть стабілізувати ситуацію. Важливо, що сам перелік завдань, які ставились перед миротворчою місією не вказувався. Третій пункт пропонував Генеральному секретареві представляти звіти на розгляд РБ ООН за необхідністю ${ }^{4}$.

Незважаючи на прийняття резолюції №143, бельгійські десантники продовжували прибувати на свої конголезькі бази, а також зміцнювати позиції у провінції Катанга, сприяючи поширенню сепаратизму в ній. Все це викликало все більше занепокоєння та протест уряду в Леопольдвілі. Паралельно зі зверненням до ООН, Ж. Касавубу та П. Лумумба 14 липня 1960 р. надіслали лист до СРСР із проханням стежити за розвитком ситуації в Конго, сподіваючись прискорити виведення бельгійських військ.

15 липня 1960 р. до Конго почали прибувати перші миротворчі контингенти з країн Африки, переважно, Гани, Тунісу, Марокко та Ефіопії. На 17 липня 1960 р. їх чисельність становила 3,5 тис., а до кінця липня того ж року - понад 11 тис. миротворців. Керівником місії ООН в Конго, що отримала офіційну абревіатуру «ONUC», став шведський генерал-майор Карл фон Хорн ${ }^{5}$. На заклик Генерального секретаря ООН про надання технічної та економічної допомоги, США силами своїх ВПС взяли участь в операціях щодо перевезення військ і техніки з різних країн до Леопольдвіля.

\footnotetext{
${ }^{1}$ FRUS (1960). Memorandum of Telephone Conversation Between President Eisenhower and Secretary of State Herter (July 12), XIV, Africa, 1958-1960. Doc. 117.

${ }^{2}$ FRUS (1960). Memorandum of Telephone Conversation Between President Eisenhower and Secretary of State Herter (July 13), XIV, Africa, 1958-1960. Doc. 120.

${ }^{3}$ James, K. (1989). The United States and the Congo from June 30, 1960 to January 17, 1961. College Park, 26.

${ }^{4}$ United Nations Security Council (1960). Resolution 143 of 14 July <https://undocs.org/S/RES/143(1960)>

(2021, вересень, 21).

5 Там само.
} 
Сполучені Штати надали в розпорядження ООН 10 літаків DC-3 і значну кількість гелікоптерів для спрямування миротворчих контингентів на територію Конго, крім Катанги. Також було надано 50 техніків ВПС США для здійснення допомоги ООН у підтриманні працездатності аеропорту Леопольдвіля ${ }^{1}$. Крім того, американська сторона передала урозпорядження Спецпредставника Генерального секретаря Р. Банча продовольчі ресурси, зокрема, $300 \mathrm{~T}$ борошна, на потреби забезпечення $\mathrm{ONUC}^{2}$. За дорученням президента Д. Ейзенхауера, на території Нігерії планувалося створити плацдарм, через який до Конго мали прибувати всі війська і необхідне постачанняз․

Уряд П. Лумумби рішуче наполягав на якомога швидшому виведенні бельгійських військ 3 території Конго, в т. ч. і з Катанги, вважаючи, що дії Брюсселя є причиною розгортання сепаратизму в провінції. Цією ситуацією прагнули скористатися у Москві, оскільки саме СРСР єдиним у РБ ООН послідовно підтримував конголезький уряд у питанні про виведення бельгійського військового контингенту.

Під час прес-конференції 21 липня 1960 р. К. Гертер зачитав заяву щодо ситуації в Конго. Він назвав спроби радянського тиску на ООН і погрози можливої інтервенції безвідповідальними і зазначив, що США «продовжать зі всією своєю моральною силою та матеріальними ресурсами підтримувати дії ООН із відновлення миру та порядку» ${ }^{4}$. Зокрема, було повідомлено, що для потреб місії ООН в Конго США нададуть додатковий транспорт та ще 400 т продовольства. Також йшлося про використання літаків ВПС США для переміщення та повернення бельгійських військ 3 Леопольдвіля на їх базу в Кітоні 5 .

22 липня 1960 р. відбулося 879-те засідання РБ ООН, присвячене конголезькому питанню. На ньому було прийнято резолюцію №145, яка містила п’ять пунктів, основну увагу з яких звертають два з них. Сам текст резолюції мав компромісний характер, оскільки враховував позиції різних сторін, зокрема, радянську та американську. Так, у пункті 1 містився заклик до уряду у Брюсселі негайно виконати постанову резолюції №143 РБ щодо виведення бельгійських військ. Для цього на Генерального секретаря ООН покладався обов'язок вжити необхідні заходи, перелік яких не уточнювався. Пункт 2 пропонував всім державам утримуватися від будь-яких дій, які могли б завадити відновленню законності і порядку, а також здійсненню урядом Конго своїх повноважень. Також передбачалося не допускати будь-яких дій, які могли б підірвати територіальну цілісність та політичну незалежність Республіки Конго ${ }^{6}$.

П. Лумумба під час урядової прес-конференції схвально відгукнувся на прийняття резолюції ООН №145, заявивши, що допомога від комуністичних країн тепер не знадобиться. 23 липня 1960 р. конголезький прем'єр-міністр відбув із незапланованим візитом до США, де сподівався провести переговори у Білому домі та штаб-квартирі ООН. 25 липня 1960 р. відбулася серія зустрічей П. Лумумби з представниками держав-членів РБ ООН та делегаціями з дев'яти африканських країн, присутніх на сніданку на честь конголезького лідера.

У Вашингтоні П. Лумумбу зустріли досить прохолодно. Так, президент Д. Ейзенхауер через постійного представника США при ООН Г. Лоджа передав, що не зможе зустрітися з прем’єрміністром Конго 727 липня 1960 р. відбулися півгодинні переговори П. Лумумби із держсекретарем США К. Гертером та його заступником Д. Ділоном. Конголезький лідер звернувся 3 проханням здійснити тиск на Брюссель щодо виведення бельгійських військ з усієї території Конго, включаючи Катангу. Також його цікавило, чи готові США надати додаткову економічну допомогу. У відповідь було заявлено, що питання виведення бельгійського контингенту відображено в резолюціях РБ ООН, а вся економічна і технічна допомога буде надана американським урядом виключно через місію ONUC, щоб не створювати прецедент для інших країн ${ }^{8}$. П. Лумумба залишився незадоволеним

\footnotetext{
${ }^{1}$ Williams, M. (1991). America and the first Congo Crisis, 1960-1963. Irvine: University of California, 23.

${ }^{2}$ FRUS (1960). Memorandum of Telephone Conversation between Secretary of State Herter and the Ambassador in Belgium (July 14), XIV, Africa, 1958-1960. Doc. 125.

${ }^{3}$ FRUS (1960). Memorandum of Conference with President Eisenhower (July 19), XIV, Africa, 1958-1960. Doc. 135.

${ }^{4}$ Editorial Note (July 21), XIV, Africa, 1958-1960. Doc. 141.

${ }^{5}$ FRUS (1960). Memorandum of Telephone Conversation Between Secretary of State Herter and the Under Secretary of State for Political Affairs (July 21), XIV, Africa, 1958-1960. Doc. 142.

${ }^{6}$ United Nations Security Council (1960). Resolution 145 of 22 July <https://undocs.org/S/RES/145(1960)>

(2021, вересень, 21).

${ }^{7}$ FRUS (1960). Telegram From the Mission at the United Nations to the Department of State (July 26), XIV, Africa, 1958-1960, Doc. 151.

${ }^{8}$ FRUS (1960). Memorandum of Conversation (July 27), XIV, Africa, 1958-1960. Doc. 152.
} 
підсумками свого візиту, не досягши поставлених цілей. Перед вильотом з Вашингтона 29 липня 1960 р., він провів короткий брифінг, де заявив про право свого уряду приймати допомогу від будьякої країни, яка погодиться іiї надати ${ }^{1}$.

1 серпня 1960 р. під час 454-го засідання РНБ США розглядалося питання про реакцію Вашингтону у випадку військового втручання з боку СРСР у справи Конго. Президент Д. Ейзенхауер заявив, що такі дії СРСР в Конго мали б характер не лише акту проти місії $\mathrm{OOH}$, але й викликали б безпосереднє залучення з боку США. Відповідно, Сполучені Штати повинні бути готові в будь-який час здійснити необхідні військові дії, потрібні для запобігання або перемоги над радянською військовою інтервенцією в Конго ${ }^{2}$. Крім того, було вказано, що на додаток до вже виділених 200 млн. дол. на потреби американської технічної допомоги в Конго, потрібно закласти ще 100 або 150 млн. дол. за рахунок Резервного фонду Конгресу США Д. Ейзенхауер у Спеціальному посланні до Конгресу надав пропозицію збільшити асигнування резервного фонду взаємної безпеки на 100 млн. дол. ${ }^{4}$

Занепокоєння у Вашингтоні можливим втручанням з боку СРСР у справи Конго не були безпідставними. П. Лумумба, не домігшись на Заході підтримки своїх планів щодо Катанги, почав шукати іiі на Сході. Так, 31 липня 1960 р., повертаючись зі свого тижневого туру до США і Канади, він знову прилетів до штаб-квартири ООН у Нью-Йорку, де зустрівся із заступником міністра закордонних справ СРСР А. Кузнєцовим, що в той час теж перебував там. 1 серпня 1960 р. СРСР оголосив про призначення свого першого посла у Леопольдвілі, яким став Михайло Яковлєв. Крім того, у Москві заявили, що готові вжити заходів для усунення бельгійської інтервенції, для чого буде надано великий пакет економічної та технічної допомоги Конго на двосторонній основі ${ }^{5}$.

Щодо питання Катанги 9 серпня 1960 р. відбулося окреме 886-те засідання РБ ООН, за підсумками якого було прийнято резолюцію №146. У преамбулі відзначався прогрес, досягнутий $\mathrm{OOH} \mathrm{щодо} \mathrm{виконання} \mathrm{попередніх} \mathrm{резолюцій} \mathrm{РБ} \mathrm{щодо} \mathrm{Республіки} \mathrm{Конго,} \mathrm{за} \mathrm{винятком} \mathrm{провінції}$ Катанга. У пункті 2 містився заклик до уряд Бельгії негайно вивести свої війська із провінції Катанга в терміновому порядку, визначеному Генеральним секретарем, а також сприяти всіма можливими способами виконанню резолюцій РБ. У пункті 3 було заявлено, що вступ військ ООН до провінції Катанга $€$ необхідним для повного втілення даної резолюції. Пункт 4 підкреслював невтручання ООН у внутрішні конфлікти між різними силами в Конго 6 .

В той час, коли в ООН відбувалося обговорення кризової ситуації в одній конголезькій провінції, виникла проблема в іншій. 8 серпня 1960 р., колишній соратник конголезького прем'єрміністра, Альбер Калонджі оголосив про утворення «Гірничорудної держави Південне Касаї» зі столицею у м. Бакванга. Напередодні, 5 серпня 1960 р., посол Бельгії у Вашингтоні Л. де Шейвен повідомляв, що ситуація в провінції Касаї викликає занепокоєння, не виключаючи сповзання до протистояння на племінному грунті ${ }^{7}$.

У ситуації подальшого поширення сепаратизму та втрати керованості країною, Конго поставало на порозі ще i внутрішньої політичної кризи. Так, 12 серпня 1960 p. посол США у Конго К. Тімберлейк повідомляв Держдепартамент про перспективу політичного протистояння між прихильниками i противниками П. Лумумби ${ }^{8}$. США готові були підтримати опозиційні до конголезького прем'єр-міністра політичні сили, однак, поки не бачили якісної альтернативи особі П. Лумумби 9

\footnotetext{
${ }^{1}$ Мазов, С. (2015). Холодная война в «сердие» Африки. СССР и Конголезский кризис, 1960-1964. Москва: Русский Фонд Содействия Образованию и Науке, 54.

${ }^{2}$ FRUS (1960). Memorandum of Discussion at the 454th Meeting of the National Security Council (August 1), XIV, Africa, 1958-1960. Doc. 156.

${ }^{3}$ FRUS (1960). Memorandum of Conference With President Eisenhower (August 1), XIV, Africa, 1958-1960. Doc. 157.

${ }^{4}$ Eisenhower, D. D. (1960). Special Message to the Congress upon its reconvening, 1960. Public Papers of the presidents of the United States. 1960-1961, August 8.

${ }^{5}$ Williams, M. (1991). America and the first Congo Crisis, 1960-1963. Irvine: University of California, 33.

${ }^{6}$ United Nations Security Council (1960). Resolution 146 of 9 August $1960<\mathrm{https} / / /$ undocs.org/S/RES/146(1960)> (2021, вересня, 21).

${ }^{7}$ FRUS (1960). Memorandum of Conversation (August 5), Volume XIV, Africa, 1958-1960. Doc. 163.

${ }^{8}$ FRUS (1960). Telegram From the Embassy in the Congo to the Department of State, Leopoldville (August 12, 1960), XIV, Africa, 1958-1960. Doc. 172.

${ }^{9}$ FRUS (1960). Telegram From the Department of State to the Embassy in the Congo (August 12), XIV, Africa, 1958-1960. Doc. 173.
} 
У цей час сам П. Лумумба наполегливо шукав вирішення ситуації, що склалася та увійшов у прямий конфлікт із Генеральним секретарем ООН. 15 серпня 1960 р. він заявив Д. Хаммаршельду, що уряд Конго втратив довіру до Генерального секретаря. Він просив РБ ООН направити спостерігачів з ряду визначених країн для повного і негайного виконання всіх трьох прийнятих резолюцій щодо Конго. Такі заяви ставили під питання майбутнє миротворчої місії ONUC. У Вашингтоні вважали, що за діями конголезького уряду стоїть $\mathrm{CPCP}^{2}$, а також, що виведення військ $\mathrm{OOH}$ з Конго матиме катастрофічні наслідки та надасть ініціативи комуністичним силам ${ }^{3}$.

Сполучені Штати шукали шляхи як не допустити припинення мандату місії ООН в Конго. Розроблялися різні варіанти починаючи від впливу на позицію П. Лумумби, аж до заміни конголезького прем'єр-міністра ${ }^{4}$. 23 серпня $1960 \mathrm{p}$. Секретаріат ООН оголосив про створення Консультативного комітету щодо операції ООН в Конго, до складу якого мали увійти представники зі всіх країн-членів місії ONUC5

22 серпня 1960 р. П. Лумумба заявив, що в цілому задоволений напрямом дій РБ ООН. Однак, у Вашингтоні на той час вже знали, що конголезький прем'єр-міністр після переговорів з радянським послом М. Яковлєвим вже мав домовленість про пакет військової допомоги від СРСР для Конго. Ще 18 серпня 1960 р. підрозділ ЦРУ в Леопольдвілі в Телеграмі №0772 повідомив Вашингтон, що в Конго відбувається класична комуністична спроба захоплення влади ${ }^{6}$. Також зазначалося, що незалежно від того, є П. Лумумба комуністом чи лише вдає його перед радянським урядом, залишилося небагато часу вжити заходів, щоб уникнути нової Куби або Гвінеї ${ }^{7}$.

Отримання навіть обмеженої військової підтримки СРСР дозволило П. Лумумбі 23 серпня 1960 р. розпочати воєнну операцію проти сепаратистів у Південному Касаї, що викликало жорстоку різанину на племінній основі. Перспектива відновлення територіальної цілісності Конго за допомогою радянської зброї, загрожувала посиленню позицій СРСР не лише в окремій республіці, але й в регіоні Субсахарської Африки загалом. Недопущення такого сценарію вимагало більш рішучої і жорсткої реакції США, що спричинило державний переворот у вересні 1960 р., усунення П. Лумумби від влади і вислання радянських представників з території Конго.

Отже, політика США щодо Конго за часів адміністрації Д.Ейзенхауера, що здійснювалася через офіційні дипломатичні представництва і неформальний підрозділ ЦРУ в Леопольдвілі, а також на міжнародній арені, зокрема, в ГА та РБ ООН, була спрямована на стабілізацію ситуації в новій країні через розгортання Миротворчої місії ООН на ії території. В період липня-серпня 1960 р., діючи винятково через інструменти та механізми $\mathrm{OOH}$, утримуючись від надання прямої допомоги конголезькому уряду, США прагнули не допустити аналогічного безпосереднього залучення у справи Конго з боку СРСР. Однак, радянський уряд наприкінці серпня 1960 р. пішов на надання допомоги уряду П. Лумумби, яка мала обмежений характер, але відбувалася в обхід процедур ООН. Ці дії спровокували ризик поширення Холодної війни в Субсахарській Африці та спричинили зміну політики США щодо Конго в наступні роки.

\section{References:}

1. Cole, B. (1967). The United Nations Peace-Keeping Operations: The Actions and Policies of the African Nations in the Congo. Washington, D.C.: Georgetown University. [in English].

2. FRUS (1960). Telegram From the Embassy in the Congo to the Department of State (July 9), XIV, Africa, 1958-1960. Doc. 109. [in English].

3. FRUS (1960). Telegram From the Embassy in Belgium to the Department of State (July 9), XIV, Africa, 1958-1960. Doc. 110. [in English].

4. FRUS (1960). Telegram From the Embassy in Belgium to the Department of State (July 10). FRUS, Volume XIV, Africa, 1958-1960. Doc. 111. [in English].

\footnotetext{
${ }^{1}$ FRUS (1960). Editorial Note (August 12), XIV, Africa, 1958-1960. Doc. 175.

${ }^{2}$ FRUS (1960). Memorandum of Discussion at the 456th Meeting of the National Security Council (August 18), XIV, Africa, 1958-1960. Doc. 180.

${ }^{3}$ FRUS (1960). Telegram From the Department of State to the Mission at the United Nations (August 16), XIV,

Africa, 1958-1960. Doc. 176.

${ }^{4}$ FRUS (1960). Telegram From the Mission at the United Nations to the Department of State (August 19), XIV, Africa, 1958-1960. Doc. 184.

${ }^{5}$ FRUS (1960). Editorial Note (August 21-22), XIV, Africa, 1958-1960. Doc. 186.

${ }^{6}$ Namikas, L. (2002). Battleground Africa: The Cold War and the Congo Crisis, 1960-1965. Los Angeles: University of Southern California, 167.

${ }^{7}$ FRUS (1960). Editorial Note (August 18), XXIII, Congo, 1960-1968. Doc. 10.
} 
5. FRUS (1960). Telegram From the Embassy in Belgium to the Department of State (July 10), XIV, Africa, 1958-1960. Doc. 113. [in English].

6. FRUS (1960). Telegram From the Embassy in Belgium to the Department of State (July 11), Volume XIV, Africa, 1958-1960. Doc. 114. [in English].

7. FRUS (1960). Telegram From the Department of State to the Mission at the United Nations (July 11), Volume XIV, Africa, 1958-1960. Doc. 115. [in English].

8. FRUS (1960). Memorandum of Telephone Conversation Between President Eisenhower and Secretary of State Herter (July 12), XIV, Africa, 1958-1960. Doc. 117. [in English].

9. FRUS (1960). Memorandum of Telephone Conversation Between President Eisenhower and Secretary of State Herter (July 13), Volume XIV, Africa, 1958-1960. Doc. 120. [in English].

10. FRUS (1960). Memorandum of Telephone Conversation between Secretary of State Herter and the Ambassador in Belgium (July 14), XIV, Africa, 1958-1960. Doc. 125. [in English].

11. FRUS (1960). Memorandum of Conference With President Eisenhower (July 19), XIV, Africa, 1958-1960. Doc. 135. [in English].

12. FRUS (1960). Editorial Note (July 21). FRUS, Volume XIV, Africa, 1958-1960. Doc. 141. [in English].

13. FRUS (1960). Memorandum of Telephone Conversation Between Secretary of State Herter and the Under Secretary of State for Political Affairs (July 21), XIV, Africa, 1958-1960. Doc. 142. [in English].

14. FRUS (1960). Telegram From the Mission at the United Nations to the Department of State (July 26), XIV, Africa, 1958-1960. Doc. 151. [in English].

15. FRUS (1960). Memorandum of Conversation (July 27), XIV, Africa, 1958-1960. Doc. 152. [in English].

16. FRUS (1960). Memorandum of Discussion at the 454th Meeting of the National Security Council (August 1), XIV, Africa, 1958-1960. Doc. 156. [in English].

17. FRUS (1960). Memorandum of Conference With President Eisenhower (August 1), XIV, Africa, 1958-1960. Doc. 157. [in English].

18. FRUS (1960). Memorandum of Conversation (August 5), XIV, Africa, 1958-1960. Doc. 163. [in English].

19. FRUS (1960). Telegram From the Embassy in the Congo to the Department of State (August 12), XIV, Africa, 1958-1960. Doc. 172. [in English].

20. FRUS (1960). Telegram From the Department of State to the Embassy in the Congo, (August 12), XIV, Africa, 1958-1960. Doc. 173. [in English].

21. FRUS (1960). Editorial Note (August 12), XIV, Africa, 1958-1960. Doc. 175. [in English].

22. FRUS (1960). Telegram From the Department of State to the Mission at the United Nations (August 16, 1960), XIV, Africa, 1958-1960. Doc. 176. [in English].

23. FRUS (1960). Memorandum of Discussion at the 456th Meeting of the National Security Council (August 18), XIV, Africa, 1958-1960. Doc. 180. [in English].

24. FRUS (1960). Telegram From the Mission at the United Nations to the Department of State (August 19), XIV, Africa, 1958-1960. Doc. 184. [in English].

25. FRUS (1960). Editorial Note (August 21-22), XIV, Africa, 1958-1960. Doc. 186. [in English].

26. FRUS (1960). Editorial Note (August 18), XXIII, Congo, 1960-1968. Doc. 10. [in English].

27. James, K. (1989). The United States and the Congo from June 30, 1960 to January 17, 1961. College Park. [in English].

28. Kabwit, G. (1975). The evolution of the Congo foreign policy from 1960-1970: A case study in the determinants influencing the making of foreign policy. Washington: The American University. [in English].

29. Mazov, S. (2015). Kholodnaya voyna v «serdtce Afriki». SSSR i congolezskiy krizis, 1960-1964 [The Cold war in the heart of Africa. USSR and Congolese crisis]. Moskwa: Russkiy Fond Sodeystviya Obrazovaniyu i Nauke. [in Russian].

30. Mountz, W. (2014). Americanizing africanization: the Congo Crisis, 1960-1967. Columbia: The University of Missouri-Columbia. [in English].

31. Namikas, L. (2002). Battleground Africa: The Cold War and the Congo Crisis, 1960-1965. Los Angeles: University of Southern California. [in English].

32. Souleyman, S. (2013). Cold War battleground in Africa: American foreign policy and the Congo Crisis, January 1959 - January 1961. Fayetteville: University of Arkansas. [in English].

33. Dwight D. Eisenhower (1960). Special Message to the Congress upon its reconvening. Public Papers of the presidents of the United States, 1960-1961. [in English].

34. Williams, M. (1991). America and the first Congo Crisis, 1960-1963. Irvine: University of California. [in English].

35. United Nations Security Council (1960). Resolution 143 of 14 July <https://undocs.org/S/RES/143(1960)> (2021, September, 21). [in English].

36. United Nations Security Council (1960). Resolution 145 of 22 July <https://undocs.org/S/RES/145(1960)> (2021, September, 21). [in English].

37. United Nations Security Council (1960). Resolution 146 of 9 August $1960<$ https://undocs.org/S/RES/146(1960)> (2021, September, 21). [in English]. 